\title{
Effects of Monoculture, Crop Rotation, and Soil Moisture Content on Selected Soil Physicochemical and Microbial Parameters in Wheat Fields
}

\author{
A. Marais, ${ }^{1}$ M. Hardy, ${ }^{1}$ M. Booyse, ${ }^{2}$ and A. Botha ${ }^{3}$ \\ ${ }^{1}$ Western Cape Department of Agriculture, Institute for Plant Production, Private Bag X1, Elsenburg 7607, South Africa \\ ${ }^{2}$ Biometry Unit, Agricultural Research Council, Private Bag X5013, Stellenbosch 7599, South Africa \\ ${ }^{3}$ Department of Microbiology, Stellenbosch University, Private Bag X1, Matieland 7602, South Africa
}

Correspondence should be addressed to A. Marais, aneliam@elsenburg.com

Received 28 June 2012; Accepted 28 August 2012

Academic Editor: D. L. Jones

Copyright (c) 2012 A. Marais et al. This is an open access article distributed under the Creative Commons Attribution License, which permits unrestricted use, distribution, and reproduction in any medium, provided the original work is properly cited.

\begin{abstract}
Different plants are known to have different soil microbial communities associated with them. Agricultural management practices such as fertiliser and pesticide addition, crop rotation, and grazing animals can lead to different microbial communities in the associated agricultural soils. Soil dilution plates, most-probable-number (MPN), community level physiological profiling (CLPP), and buried slide technique as well as some measured soil physicochemical parameters were used to determine changes during the growing season in the ecosystem profile in wheat fields subjected to wheat monoculture or wheat in annual rotation with medic/clover pasture. Statistical analyses showed that soil moisture had an over-riding effect on seasonal fluctuations in soil physicochemical and microbial populations. While within season soil microbial activity could be differentiated between wheat fields under rotational and monoculture management, these differences were not significant.
\end{abstract}

\section{Introduction}

Soil quality is essential for plant and animal health, maintenance of the environment, and sustained biological productivity [1]. Soil microbes play a pivotal role in maintaining soil quality $[2,3]$. Microbial diversity of the rhizosphere is believed to be beneficial for soil health [4] and the trophic interactions within the rhizosphere can affect the aboveground community of plants [5]. Our understanding of soil microbial functioning in this plant-microbe interaction has generally been limited $[6,7]$.

Plant variety has a significant influence on the associated soil microbial community, as measured by community-level physiological profiling (CLPP) by Dunfield and Germida [8]. These authors also found that seasonal differences in this community were not permanent. Marschner et al. [9] found that the rhizosphere microbial community was plant species-specific, while Morgan et al. [4] stated that the root exudates from different plants and even different cultivars of the same plants differed and these caused differences in the rhizosphere communities associated with the plants. Thus, it could be expected that the microbial communities under wheat monoculture and wheat in rotation with legume pasture would differ significantly.

Various role players are more frequently requesting information on the impact of land use management practices on the physical, chemical, and biological fertility of soils [1]. There exists little knowledge about how management systems influence microbial communities and as a result the fertility of the soil [10]. When physicochemical properties of a soil are altered by agricultural practices, the microbial community may respond to these changes $[11,12]$.

In recent years, soil microbial diversity was estimated using molecular methods. However, it was found that diversity indices based on DNA heterogeneity may be ambiguous especially when determined for soils containing a high diversity of microbes [13]. Wintzingerode et al. [14] concluded that molecular analysis of an environment often leads to a distorted view of the diversity of an ecosystem. The methods used to extract DNA from the soil also affect 
the results of diversity estimations [15]. These methods are also costly and require a high level of expertise. Although only a small fraction of soil microbes is culturable [16-18], some researchers [19-21] found that culturable microbial populations could act as indicators of soil health. Olsen and Bakken [19] found that the energy flow via the non-colony forming microbial population is a very small fraction of that of the whole of the soil ecosystem, while Ellis et al. [20] found that monitoring colony forming bacteria was a useful tool in determining the effect of anthropogenic actions. Edenborn et al. [21] described culturable bacteria as being useful in indicating selected agronomic disturbances as well as adding to our understanding of the link between microbes and environmental processes.

There seems to be a clear relationship between soil microbial diversity, soil, and plant quality [5], as well as ecosystem sustainability [22] and it is known that crop rotation benefits wheat yield $[23,24]$. The question now arises: can agricultural management practices bring about changes in the soil's physicochemical and biological propertiesthe ecosystem profile-of a wheat field? This study was conducted to evaluate selected soil physicochemical and microbial parameters under two different management systems, namely, wheat monoculture and wheat in rotation with annual legume pastures.

\section{Materials and Methods}

2.1. Experimental Site. The study was conducted during winter and spring each year from 2006 to 2009 within a long-term crop rotation trial that was initiated in 1996 at the Langgewens experimental farm in the Western Cape. Langgewens ( $\left.18^{\circ} 42^{\prime} 0.004^{\prime \prime} \mathrm{E}, 33^{\circ} 16^{\prime} 59.873^{\prime \prime} \mathrm{S}\right)$, near Moorreesburg, is situated in one of the most important wheat producing regions of South Africa. The region experiences a typical Mediterranean climate with hot, dry summers, and cool, moist winters. Long-term ( $n=68$ years) average annual precipitation is $398.2 \mathrm{~mm}$ per annum, of which approximately $80 \%$ occurs during the period from April to September. The long-term mean daily maximum and minimum temperatures ranged between $24.9^{\circ} \mathrm{C}$ and $13.7^{\circ} \mathrm{C}$ in April, through $17.0^{\circ} \mathrm{C}$ and $8.1^{\circ} \mathrm{C}$ in July, and $20.2^{\circ} \mathrm{C}$ and $9.2^{\circ} \mathrm{C}$ in September, respectively ( $n=39$ years). Mean monthly rainfall from 2006 to 2009 is presented in Figure 1.

Soils are mainly of the Mispah and Glenrosa soil forms [25] with an average A-horizon depth of 200 to $400 \mathrm{~mm}$ and a sandy loam to loam texture. The A-horizon typically has an organic carbon content that ranges from $0.8 \%$ to $1.2 \%$ and a stone content of $45 \%$. The B-horizon of the Glenrosa soil form is well-weathered yellow/red clay above poorly weathered schist while that of the Mispah soil form is poorly weathered schist. Since these soils tend to become waterlogged, the trial site was "ridge-and-furrowed" prior to the start of the trial.

2.2. Experimental Layout. Six $60 \mathrm{~m} \times 30 \mathrm{~m}$ experimental plots, within the long-term trial site, were selected for the present study. Two of the plots had been planted to spring wheat each year since 1996 (hereafter referred to

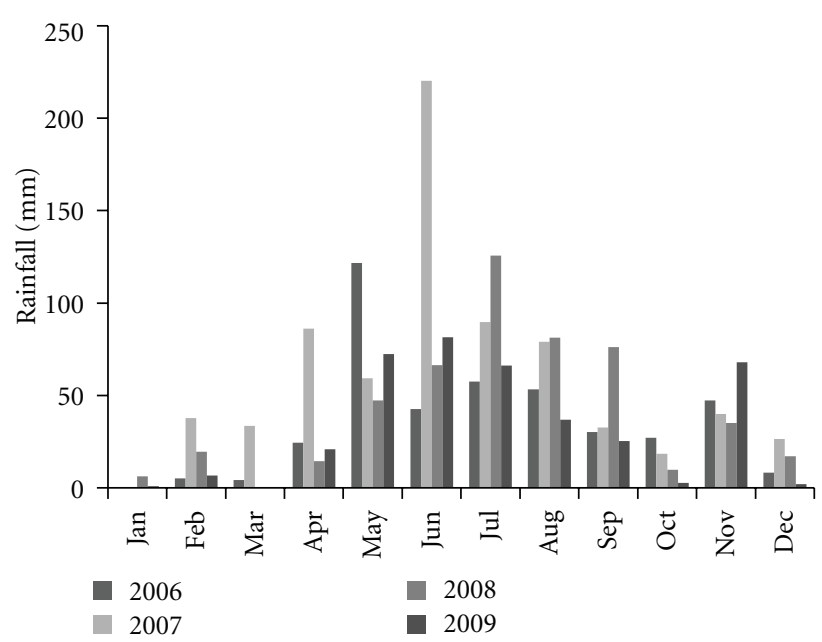

Figure 1: Average monthly rainfall during the test period.

as "monoculture"). Each of the remaining four plots were planted to a wheat/legume-pasture rotation system with spring wheat and annual legume pastures being produced in each plot in alternate years since 1996 (hereafter referred to as "rotation"). Two of the rotation plots were planted to wheat in 1996 and the other two rotation plots were planted to annual legume pastures in 1996. Therefore, for the rotation plots, there were two wheat plots and two pasture plots available to the present study each year. The annual legumes present during the pasture phase of the wheat/pasture rotation comprised a mixture of Medicago truncatula cultivars, namely, Parabinga, Sephi, and Mogul. The spring wheat cultivar SST 027 was planted in all monoculture and rotation plots in the wheat phase in all four years of the present study.

To facilitate sampling, each of the six experimental plots (two monoculture and four rotation) was divided evenly into six contiguous minor plots that were sequentially numbered from 1 to 6 . Each minor plot measured $10 \mathrm{~m} \times 30 \mathrm{~m}$.

2.3. Crop Management. Planting, crop protection, and harvesting activities were applied using standard farm implements and machinery following conservation farming practices. Macro and trace element concentrations were maintained at or above optimum levels for each crop as recommended by Anon [26].

Weeds were allowed to germinate and then controlled using a broad-spectrum herbicide (monoculture plot, Glyphosate $360 \quad 1.5 \quad \ell \cdot h^{-1}$ and Triasulfuron (Logran) $37.5 \mathrm{~g} \cdot \mathrm{ha}^{-1}$; rotation plot, Glyphosate $3601.5 \ell \cdot \mathrm{ha}^{-1}$ ) before planting commenced on 17 May 2006.

Prior to 2002, wheat was planted into a prepared seedbed where $100 \%$ of the soil surface of each plot was disturbed to a depth of $100 \mathrm{~mm}$ using a scarifier. From 2002, all the plots that were planted to wheat (monoculture and rotation) were planted using a no-till planter where approximately $20 \%$ of the soil surface was disturbed during planting. In the year that pastures were produced in the rotation plots, the pasture regenerated from soil-stored seed banks. 
The top soil in the rotation plots was therefore disturbed (to a depth of approximately $100 \mathrm{~mm}$ ) only once in two years when wheat was planted in the rotation plots, while topsoil disturbance occurred each year during planting in the monoculture plots. From 2006 the Australian developed, notill planter (Auseeder) was used when planting wheat. The planter has 11 planting units that are spaced $300 \mathrm{~mm}$ apart. Each planting unit consists of a knifepoint opener, a closing tool, and a press wheel and is commercially known as the Deep Blade System (DBS). Nitrogen and phosphorous were applied together with the seed in the planting row at a rate of $29 \mathrm{~kg} \mathrm{~N} . h \mathrm{a}^{-1}$ and $10 \mathrm{~kg} \mathrm{P.ha}{ }^{-1}$, respectively.

All wheat straw was baled and removed from the plots after harvesting each year from 1996 to 2001 but all wheat straw was retained on the plots following harvesting in all years subsequent to 2001. Sheep grazed the wheat residues during summer in the wheat/pasture rotation system but not in the wheat monoculture, except in 2007 when the monoculture was heavily grazed to try and combat the ryegrass infestation. In the wheat monoculture, the stubble was removed by burning prior to land preparation for planting, in all years from 1996 to 2001, but stubble was not burnt in subsequent years. In 2008, it was decided to burn the stubble in all wheat monoculture camps in an attempt to destroy seed shed by herbicide resistant ryegrass plants during the 2007 growing season in the monoculture plots, due to high ryegrass infestation. Where wheat followed the annual legume pasture, pasture residues were retained before land preparation in all years except 2008 when it was accidentally burnt.

2.4. Sampling Procedure. Sampling was conducted only on the ridges as furrows tended to become intermittently waterlogged during the growing season. Samples were collected from three of the minor plots in each of the rotation and monoculture plots on each sampling occasion. Oddnumbered minor plots were sampled in the first year while even-numbered plots were sampled in the following year. This procedure was repeated in the third and fourth years of this study.

The samples were collected within each minor plot on three occasions, namely, in June (six weeks after planting), August (15 weeks after planting), and November (just after the wheat was harvested), each year. Five soil samples (each $40 \mathrm{~mm}$ diameter and $150 \mathrm{~mm}$ deep) were randomly collected in each of the three minor plots per experimental plot. The five soil samples were bulked and mixed to provide three samples for each experimental plot on each sampling occasion for all analyses. Samples were stored in new plastic bags at $8^{\circ} \mathrm{C}$ until analysed (within two weeks of sampling).

2.5. Microbial Analyses. Soil dilution plates were used to enumerate culturable microbes in the soil samples. A $100 \mu \mathrm{L}$ aliquot of each dilution in a soil dilution series $\left(10^{-1}-10^{-5}\right)$ was transferred to a Petri dish containing the appropriate enumeration medium and spread over the surface with a sterile glass-spreading rod. Actinomycetes were cultivated on sodium caseinate agar [27] while nutrient agar [28] was used for heterotrophic microbes. The enumeration of anaerobic fungi was done on yeast malt (YM) agar (28) and incubated in anaerobic chambers. Hymenomycetous fungi were determined using a benlate-dichloran-streptomycin medium (BDS) [29] and the colonies were classified as filamentous or nonfilamentous yeast-like growth. All of the above-mentioned plates were incubated in the dark at $26^{\circ} \mathrm{C}$ for seven days after which the colony-forming units were counted manually.

For the enumeration of protozoa, the method known as most probable number (MPN) was used, as described by Rønn et al. [30]. These numbers were converted to estimated soil populations using a formula of Briones and Reichardt [31].

All the soil samples were subjected to community level physiological profiling (CLPP) [32]. Soil suspensions were prepared by transferring $10 \mathrm{~g}$ of soil to $90 \mathrm{~mL}$ of sterile distilled water. Each suspension was shaken for $10 \mathrm{~min}$ on a wrist shaker and allowed to settle for two hours, after which $100 \mu \mathrm{L}$ aliquots of the supernatant were used to inoculate the wells of Biolog EcoPlates (Biolog, Hayward, CA, USA). The inoculated plates were incubated in the dark at $22^{\circ} \mathrm{C}$ for 48 hours. Utilisation of the carbon source in each well, indicated by a reduction of the tetrazolium dye, was then recorded on a Bio-Rad Model 680 Micro Plate Reader at $595 \mathrm{~nm}$ wavelength. To correct for possible background colour effect, the reading of the control well was subtracted from the actual reading. Any possible negative results were recorded as 0 .

Filamentous growth within the soil was measured by an adaptation of the buried slide technique, [33] as described by Marais et al. [34]. Clean microscope slides were bound in pairs with masking tape. These were then buried upright in the soil at a depth of $15 \mathrm{~cm}$. After two weeks in the soil, the slides were removed and wiped clean on the outside. The inside of each slide was then examined under a light microscope at 100x magnification and filamentous growth were recorded in 20 fields on each slide. Thus the possible count was between 0 and 40 for a pair of slides. The actual number of positive fields was calculated as a fraction of the possible 40.

2.6. Physicochemical Analyses. Soil calcium and phosphorous were determined using the citric acid method, while soil organic carbon (\%) was determined using the WalkleyBlack method [26] and total nitrogen (\%) using the method described by AOAC [35]. Sulphur content (ppm) was determined using the calcium monophosphate extraction method [36] while boron content (ppm) was determined using the extractable boron hot water method [26]. Soil moisture (\%) was determined gravimetrically by weighing and then drying approximately $100 \mathrm{~g}$ of soil for four days at $60^{\circ} \mathrm{C}$. Moisture content was expressed as a percentage of the weight of dry soil.

2.7. Statistical Procedure. The data was continuous; therefore, univariate (ANOVA and $t$-tests) and multivariate analyses (cluster analysis and discriminant analysis) were performed on the data.

With the objective of comparing treatment means, the data was subjected to an appropriate analysis of variance. 


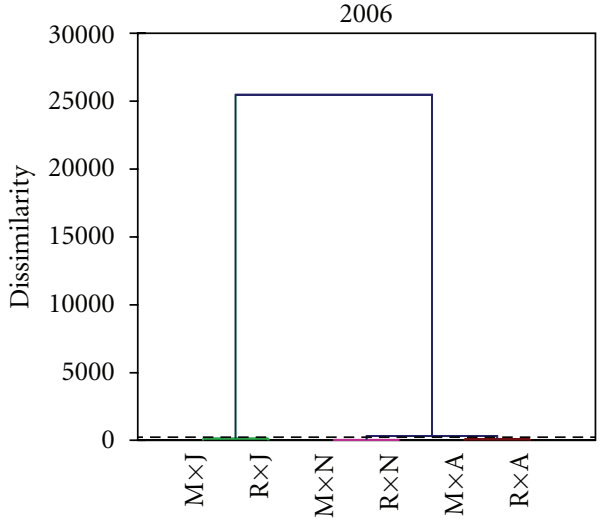

(a)

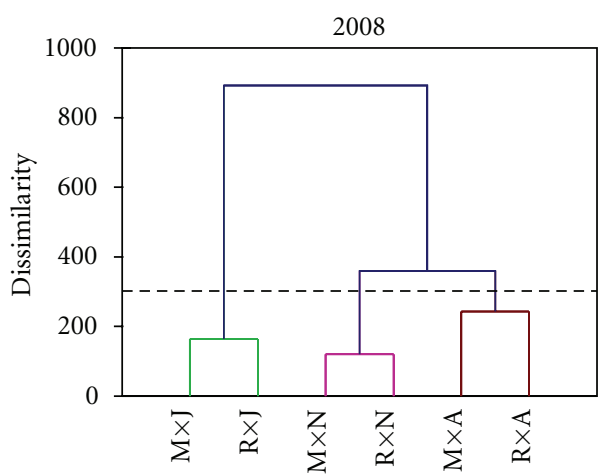

(c)

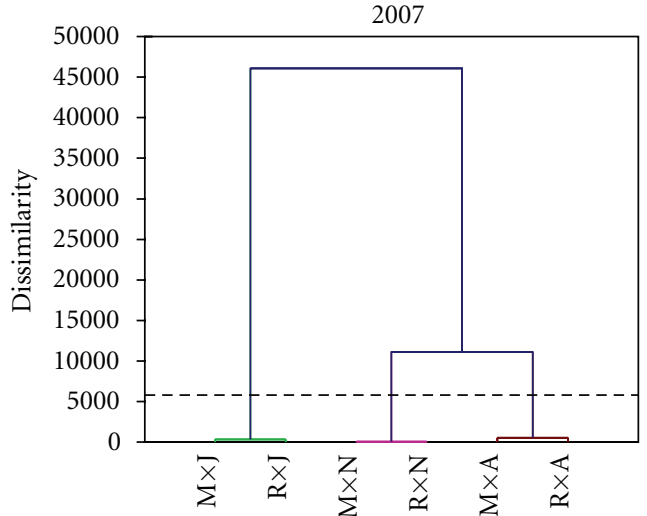

(b)

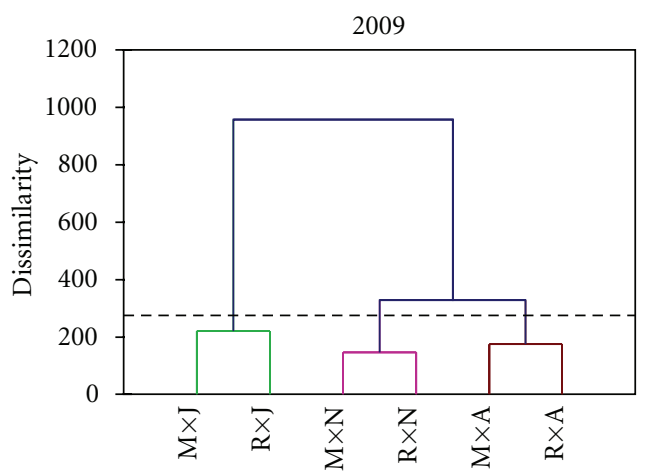

(d)

FIgURE 2: Results of cluster analyses conducted on the ecosystem profiles of the soils, comprising both physicochemical and biological variables, obtained for each year of the study $(\mathrm{M}=$ monoculture and $\mathrm{R}=$ rotation, $\mathrm{J}=$ June, $\mathrm{A}$ = August, and $\mathrm{N}=\mathrm{November})$.

The analysis of variance was performed using SAS version 9.2 [37]. The Shapiro-Wilk test was performed to test for nonnormality [38]. Student's $t$-test significant difference was calculated at the $5 \%$ significance level to compare treatment means [39].

The method of Ward [40] was used to perform cluster analysis. This method has no prior classification and groupings may be evident. A discriminant analysis (DA) was done to investigate the separation (discrimination) of the forthcoming groups. These multivariate statistical analyses were computed using XLSTAT [41] statistical software.

\section{Results and Discussion}

3.1. Physicochemical Analyses. Rainfall differed between season and years (Figure 1) with the least rain occurring in 2009 $(384 \mathrm{~mm})$ and the most rain occurring in $2007(723 \mathrm{~mm})$. Thus the rainfall during our test period varied from just under to well above the long-term $(n=68$ years) average precipitation of $398.2 \mathrm{~mm}$ per annum for the area.

Soil moisture content, as determined on the day of sampling, ranged from $2.6 \%$ to $18.1 \%$. The average daily soil temperature for the week leading up to the day of sampling ranged from 13.7 to $17.1^{\circ} \mathrm{C}$ in June, 11.4 to $14.3^{\circ} \mathrm{C}$ in August, and 23 to $25.6^{\circ} \mathrm{C}$ in November. This was usually slightly higher than the average daily air temperature for the same period, which ranged from 12.9 to $15.6^{\circ} \mathrm{C}$ in June, 11.2 to $13.2^{\circ} \mathrm{C}$ in August, and 18 to $22.8^{\circ} \mathrm{C}$ in November.

To determine whether the agricultural management type (monoculture or rotation), season, and specific year in the study period influenced the physicochemical and microbiological measured variables (see Sections 2.5 and 2.6), the data was subjected to a two-way ANOVA (analysis of variance) test. From the results (Table 1), it is clear that management type had little influence on the measured variables, while the season in which measurements were taken had the most significant influence on these variables. Interaction between season and type (monoculture or rotation) was significant for soil sulphur concentration in $2007(P=0.0453)$, the year with the highest rainfall in the study period. An interaction is the variation among the differences between means for different levels of one factor over different levels of the other factor [42]. In this instance, season had the largest effect in this interaction (means of 16 for season versus 5.4 for management type) and it is possible that the high rainfall had an effect on the overall soil sulphur levels, which is known to leach. In the rotation, however, the legume pasture would have sequestered more sulphur from the soil, since legumes are known to have a high requirement for sulphur [43], thus resulting in lower sulphur levels in the rotation soils. 


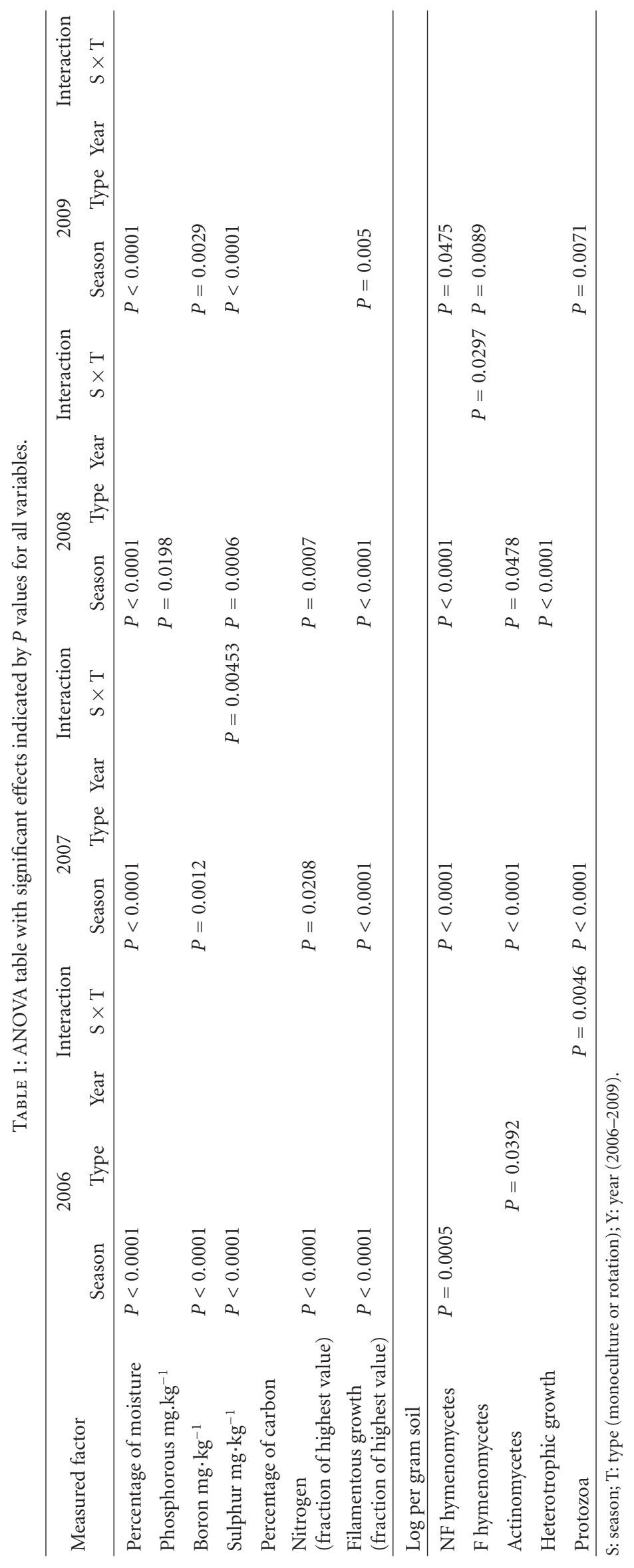


TABle 2: ANOVA table with year included as a subplot. Significant effects indicated by $P$ values for all variables.

\begin{tabular}{|c|c|c|c|c|c|c|c|}
\hline \multirow{2}{*}{ Measured factor } & \multicolumn{7}{|c|}{ Year as subplot } \\
\hline & Year & Season & Type & $\mathrm{T} \times \mathrm{S}$ & $\mathrm{Y} \times \mathrm{T}$ & $\mathrm{Y} \times \mathrm{S}$ & $\mathrm{Y} \times \mathrm{T} \times \mathrm{S}$ \\
\hline Percentage of moisture & & & & & & $P<0.0001$ & \\
\hline Phosphorous $\mathrm{mg} \cdot \mathrm{kg}^{-1}$ & $P=0.0068$ & & & & & & \\
\hline Boron $\mathrm{mg} \cdot \mathrm{kg}^{-1}$ & & & & & & $P<0.0001$ & \\
\hline Sulphur mg $\cdot \mathrm{kg}^{-1}$ & & & & & & $P<0.0001$ & \\
\hline \multicolumn{8}{|l|}{ Percentage of carbon } \\
\hline Nitrogen (fraction of highest value). & & & & & & $P<0.0001$ & \\
\hline Filamentous growth (fraction of 40) & & & & & & $P<0.0001$ & \\
\hline \multicolumn{8}{|l|}{ Log per gram soil } \\
\hline Nonfilamentous hymenomycetes & & & & & & $P<0.0001$ & \\
\hline Filamentous hymenomycetes & & & & & & $P=0.0002$ & \\
\hline Actinomycetes & & & & & & $P<0.0001$ & \\
\hline Heterotrophic growth & & & & & & $P<0.0001$ & \\
\hline Protozoa & & & & & & & $P=0.0433$ \\
\hline
\end{tabular}

S: season; T: type (monoculture or rotation); Y: year (2006-2009).

Since rainfall differed substantially over the test period, "year" was subsequently used in the equation as a subplot [44] and the measured variables were compared for the different years. Consequently, significant yearly differences in soil phosphorous levels, as well as interaction between "year" and "season" were revealed for soil moisture content, as well as the levels of boron, sulphur, and nitrogen in the soil (Table 2). These findings may be ascribed to differences in rainfall that were recorded during the four years of the test period (Figure 1).

During 2009, the driest year of the test period, soil phosphorous, and nitrogen levels seemed to be linked and were positively correlated $(r=0.983)$, as was found using Pearson's correlation. During this year, the response of both these variables, to the wetting and drying cycles of the soil, seemed to be more pronounced than during other years. In this regard, Venterink et al. [45] reported that drying as such had little effect on phosphorous, but the rewetting of dried soil caused substantial changes in the extractable phosphorous as well as the availability of nitrogen. It is known that these nutrients play a major role in soil microbial communities, especially in legumes, such as the clover/medic pasture rotation crop [46].

3.2. Microbes. When all measured physicochemical and microbial measured variables (Table 1) were subjected to cluster analyses for each year, grouping clearly separated according to season for the duration of the test period (Figures 2(a)-2(d)). This is in accordance with the ANOVA results (Table 1) that showed season as the most significant effect behind the values obtained for the measured variables. Similar results were obtained by Marais et al. [34].

When viewed per year, the only biological factor displaying significant difference between monoculture and rotation was the actinomycete counts in 2006 (Table 1: $P=0.0392$ ). Interaction between season and type was significant for protozoa in $2006(P=0.0046)$. From Figure $3(d)$, it is clear that the seasonal effect on protozoan numbers was vastly different in the soil subjected to the two management types, namely, monoculture wheat and wheat in rotation with legume pasture. The colder, wetter conditions in August caused the numbers of protozoa to drop significantly in the soil of the monoculture, while the soil protozoan numbers in the plot subjected to rotation remained fairly constant. Towards the end of the growing season, however, the reverse was true with the soil protozoan numbers of the rotation plot were falling rapidly while the numbers of these microbes in the monoculture plot increased to numbers comparable to the numbers at the beginning of the season. The year 2006 had average rainfall, but rainfall was lower in the later part of winter (August 2006) than for the same period in the other years of the experimental period (Figure 1). It is possible that the drier winter had a greater effect on the protozoa associated with the monoculture than that of the rotation. This could be in accordance with the findings of Hardy $[47,48]$ who found that during years with less than average rainfall, crops of rotation plots performed better overall. It has been suggested by Torsvik and Øvreås [49] that soil fertility is associated with "buffering" capabilities provided by soil microbes. It is therefore tempting to speculate that the dry conditions during August 2006 may have been better tolerated by the protozoan community of the rotation plots, than by the protozoa in soil of the monoculture plots.

An interesting correlation was found between the total rainfall for the period two weeks before sampling (Figure 4) and the actinomycete numbers. This positive correlation $(r=0.842)$ was highly significant in 2009, the driest year, indicating that actinomycete numbers and rainfall were linked. In the wettest year (2007), however, these variables were negatively correlated $(r=-0.855)$, so that an increase in rainfall led to a reduction in actinomycete numbers. 


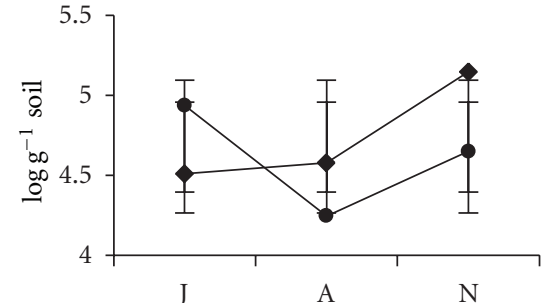

(a)

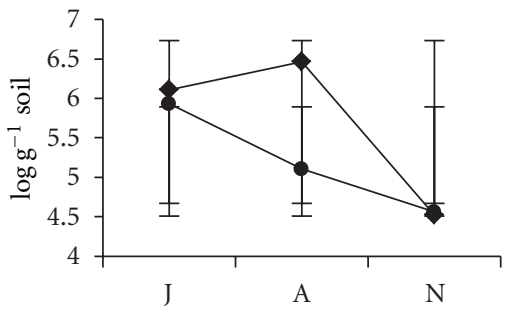

(b)

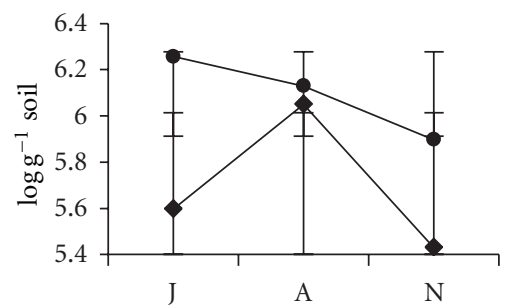

(c)

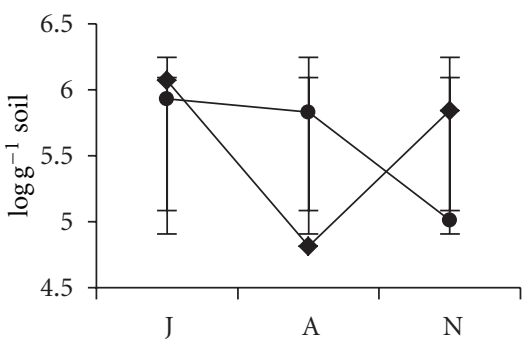

(d)

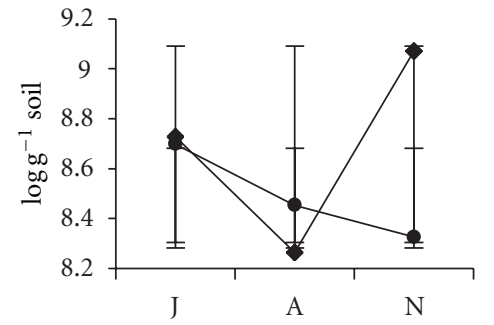

(e)

Figure 3: Microbe numbers on a logarithmic scale displaying different responses to monoculture (M) and rotation (R) in in the different seasons ( $\mathrm{J}=$ July; $\mathrm{A}=$ August; $\mathrm{N}=$ November) in 2006. Monoculture $=\mathrm{M}-\boldsymbol{-}$-; rotation $=\mathrm{R}-\bullet-$. (a) Filamentous hymenomycetes, (b) nonfilamentous hymenomycetes, (c) actinomycetes, (d) protozoa, and (e) heterotrophic counts. Vertical bars denote standard deviation.

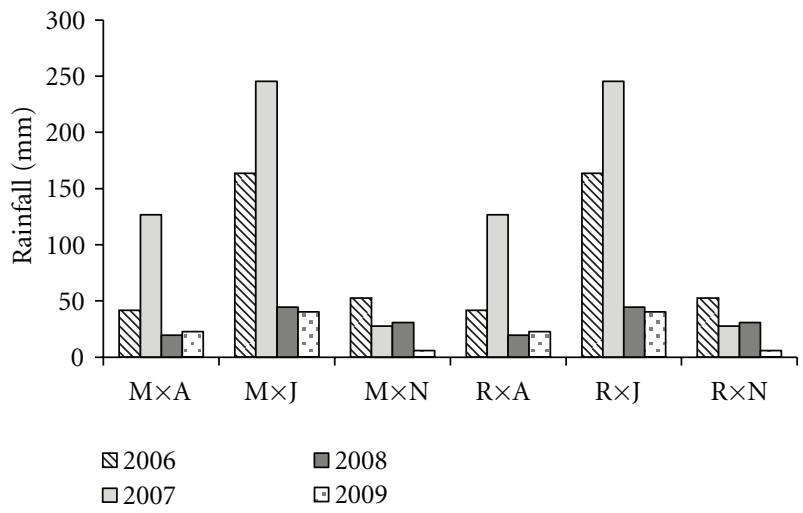

Figure 4: Accumulated rainfall two weeks prior to sampling date. Monoculture $(\mathrm{M})$ and rotation $(\mathrm{R})$ in the different seasons $(\mathrm{J}=$ July; A = August; $\mathrm{N}$ = November) (data ARC-Institute for Soil, Climate and Water, AgroClimatology Programme, Stellenbosch, South Africa).

The actinomycete numbers were also negatively correlated with soil moisture $(r=-0.822)$ in 2007. Thus, it seems that although actinomycetes need a minimum moisture level to grow, these bacteria are sensitive to waterlogged soil conditions. This is in accordance with results obtained by Titus and Pereira [50] who found than waterlogged soils could be detrimental to the actinomycetes that thrive in well-aerated soils. Similarly, protozoan numbers were positively correlated with rainfall $(r=0.880)$ and soil moisture $(r=0.953)$ in the wettest year. Protozoan numbers followed a seasonal pattern in all years and interaction occurred between season and year in 2006 (Table 1), a year with just above average $(422 \mathrm{~mm})$ rainfall. When "year"

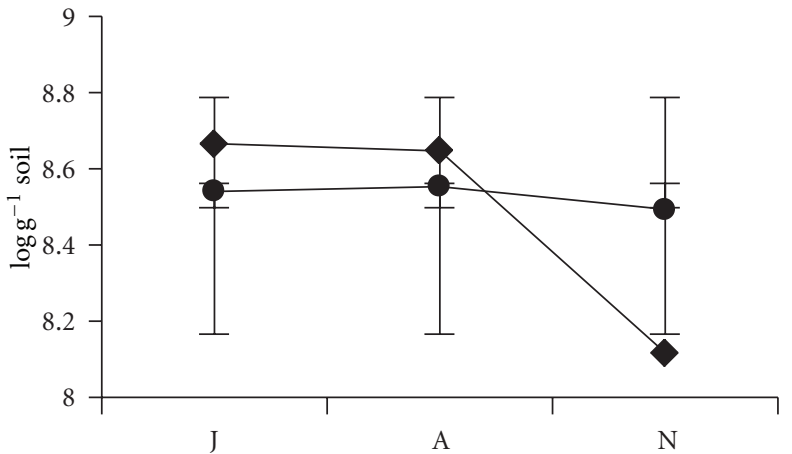

FIGURE 5: Heterotrophic counts on a logarithmic scale displaying different reactions to monoculture and rotation in the different seasons in 2007. Monoculture $=\mathrm{M}-\downarrow$-; rotation $=\mathrm{R}-\bullet-$. Vertical bars denote standard deviation.

was added as a subplot (Table 2), interaction occurred between year, season, and type. It therefore seems that something other than the availability of moisture played a role in influencing soil protozoan numbers. Since protozoa often feed on bacteria [51, 52], it is possible that the abundance of protozoa was a function of the availability of bacteria.

When the seasonal trends of the results obtained from the biological variables were plotted against the agricultural management type, some interesting patterns emerged, although they were not always statistically significant at $P=0.05$. In 2006, a year with just above average rainfall $(422 \mathrm{~mm})$, filamentous and nonfilamentous hymenomycetes, actinomycetes, and protozoa as well as 


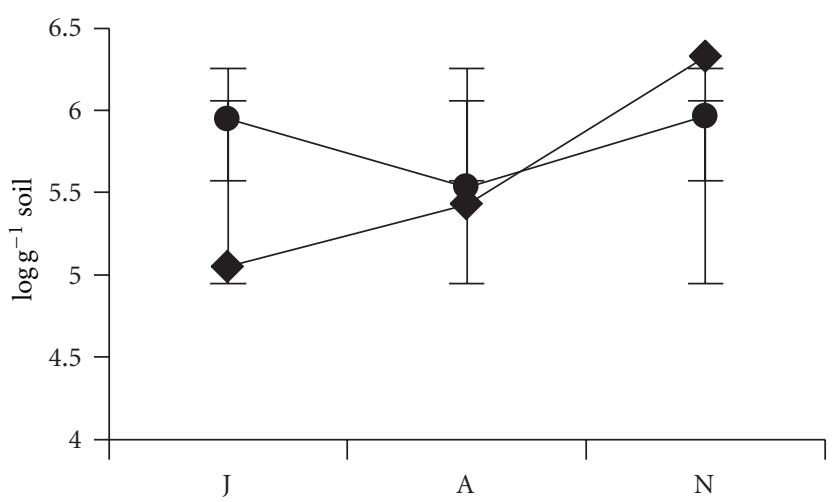

(a)

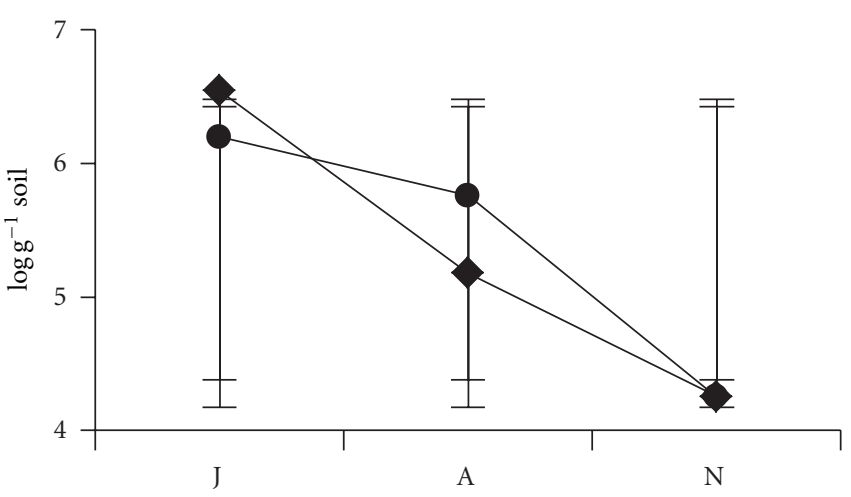

(b)

FIGURE 6: (a) Actinomycete and (b) nonfilamentous hymenomycete numbers on a logarithmic scale displaying different responses to monoculture and rotation in the different seasons in 2008. Monoculture $=\mathrm{M}-\boldsymbol{-}$; rotation $=\mathrm{R}-\bullet-$. Vertical bars denote standard deviation.

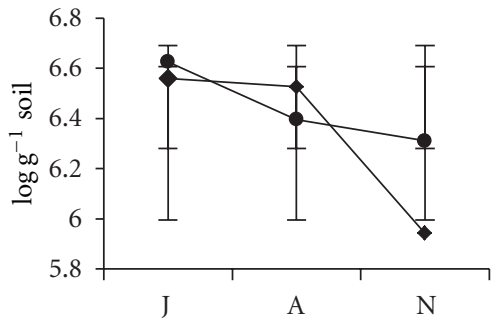

(a)

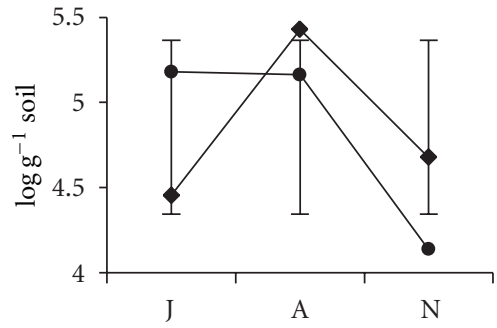

(b)

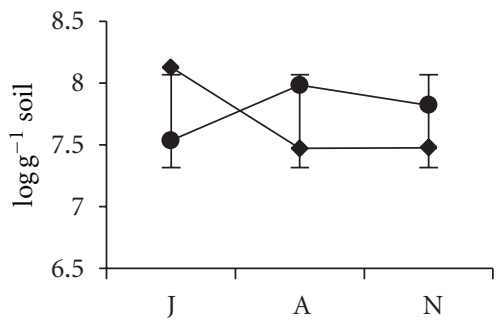

(c)

FIGURE 7: (a) Actinomycete, (b) protozoa, and (c) heterotrophic counts on a logarithmic scale displaying different reactions to monoculture and rotation in 2009. Monoculture $=\mathrm{M}-\downarrow$-; rotation $=\mathrm{R}-\bullet-$. Vertical bars denote standard deviation.

heterotrophic counts displayed different patterns in monoculture and rotation (Figure 3 ).

In 2007, the year with the highest rainfall $(723 \mathrm{~mm})$ of the study period, only heterotrophic counts displayed some difference between management practices (Figure 5) and then mostly in November, when it was drier.

In 2008, a year with above average rainfall $(500 \mathrm{~mm})$, two measured microbial parameters, namely, actinomycetes and nonfilamentous hymenomycetes, displayed slightly different reactions to the different management types (Figure 6).

In 2009, the final year of the study period and a year with just under average rainfall $(384 \mathrm{~mm})$, three measured microbial parameters displayed different reactions to the different management type. These were actinomycetes, protozoa, and heterotrophic counts (Figure 7).

When viewed over the four year study period (Figure 8), it is interesting to note that not many of the microbial parameters $(\mathrm{a}-\mathrm{g})$ followed a similar pattern to that of the soil moisture content (h), as could perhaps be expected, since ANOVA showed that soil moisture was statistically significant in all years (Table 1). It thus seems that, even though soil moisture is probably the main driving force changing the culturable soil microbial communities, other parameters also play a role. This is in accordance with results from a study done by Bachar et al. [53] who found that while bacterial abundance in soils was correlated with the water availability, the richness and diversity of the community was influenced by something else, such as nutrient availability and $\mathrm{pH}$.

From Figure 8, it is clear that in the two years in which more than average rainfall occurred, namely, 2007 and 2008, the counts for measured microbes were in some cases higher, some lower, and some similar to that in the years with average rainfall (2006 and 2009). The numbers of microbial parameters studied are thus not only linked to soil moisture, in accordance with the results obtained by Bachar et al. [53]. The colonies cultured on the facultative anaerobic medium (Figure 8(f)) were mostly found to represent the fungal order Mucorales. These fungi had slightly higher numbers in the two years with the lower rainfall. Seabi et al. [54] found that some Mucoralean fungi in South African soils were found to be tolerant to a wide range of salinity and thus the availability of water. Therefore, the lower rainfall in these two years, which is likely to have reduced populations of some of the microbes measured in our study, would not probably have adversely affected the growth of the Mucorales.

3.3. Biolog EcoPlate. The rotation system may result in a greater variety of potential microbial carbon sources in the soil, due to the legume pastures [55] and waste from the grazing sheep. Therefore, it could be expected that CLPP analyses, based on the Biolog EcoPlate method, would have 


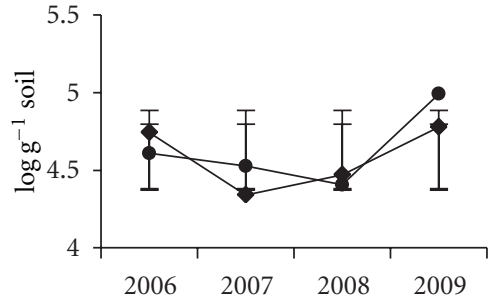

(a)

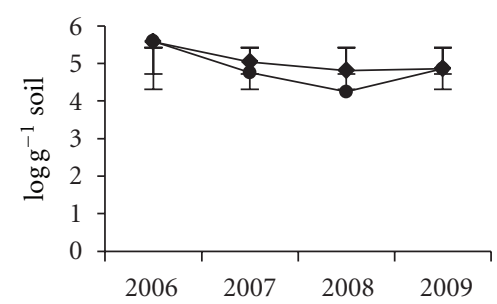

(d)

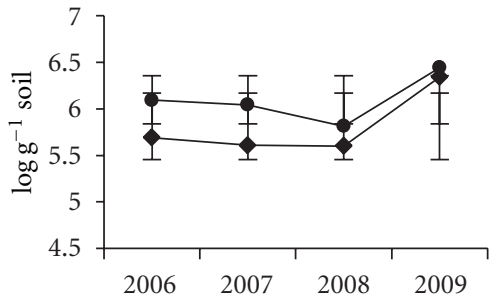

(b)

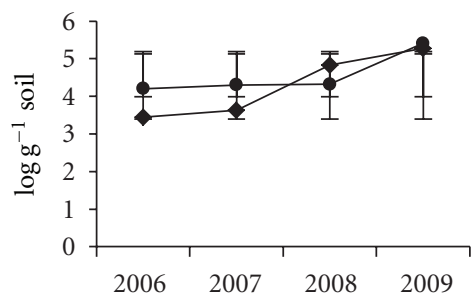

(e)

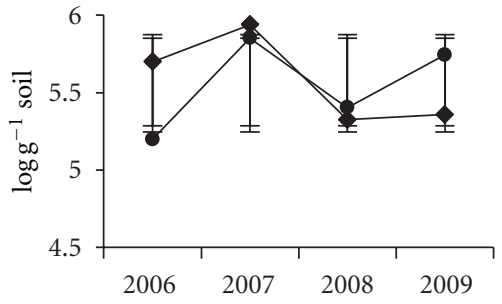

(c)

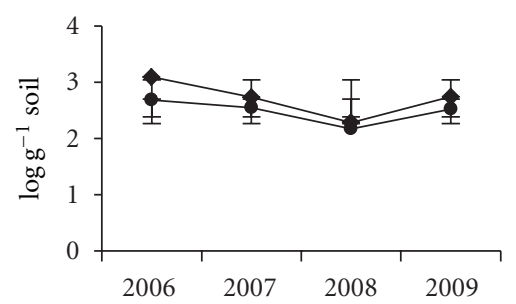

(f)

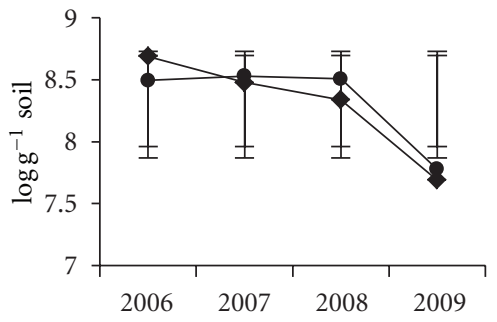

(g)

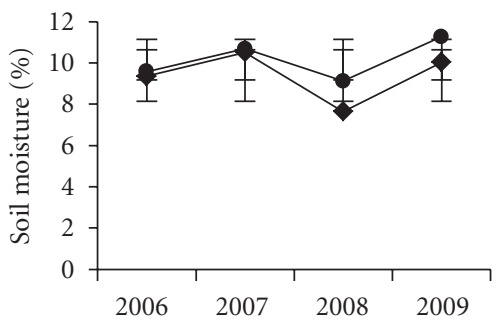

(h)

FIGURE 8: Differences in microbial numbers on a logarithmic scale and soil moisture content of plots subjected to rotation and monoculture during the study period. (a) Nonfilamentous hymenomycetes, (b) filamentous hymenomycetes, (c) actinomycetes, (d) protozoa, (e) filamentous growth, (f) Mucorales, (g) heterotrophic growth, and (h) percentage of soil moisture on day of sampling. Monoculture = M $-\downarrow-$; rotation $=\mathrm{R}-\bullet-$. Vertical bars denote standard deviation.

revealed if differences existed in the carbon sources utilised by the soil bacterial community in soils subjected to the two management systems.

When the Biolog EcoPlate data was analysed for each year, the following patterns emerged. In 2006 the data of the dendrogram as well as the discriminant analysis (DA) clearly grouped per season rather than per type (Figure 9), in accordance with the results obtained by Marais et al. [34], amongst others. Even though Biolog EcoPlate mainly measures the metabolic potential of rapidly growing bacteria [32], these results were in accordance with the results obtained in the other microbial variables measured in this study (see Section 3.2).

Data from the wettest year of the study period, namely, 2007, did not cluster much per season (Figure 10) but the discriminant analysis (DA) showed some clustering according to type, when samples from monoculture in November and August grouped together and separately from the others. It seems that when moisture is not limited, the effect of the different management systems is not so distinct.

In 2008 and 2009, the trend of 2007 mostly continued (Figures 11 and 12) with not much clustering according to season. Some clustering according to management type occurred in the DA with monoculture in November and rotation in November totally separate from each other and from the samples taken in June and August (Figure 11).

From Figures 11(a) and 11(b), it is clear that the November monoculture samples separated completely from the other samples. One of the two monoculture plots was not harvested, but sprayed with herbicide shortly before sampling in November, because of the high infestation of ryegrass weeds. It is possible that the herbicide had an effect on the soil microbial community, as reported by Marais et al. [56].

In 2009, monoculture samples taken in August, midway through the growing season, did not cluster with the other samples (Figures 12(a) and 12(b)). In 2009, the rainfall was the lowest recorded over the test period and also the lowest for the month of August, when the samples were taken (Figure 1). It is possible that the monoculture experienced more stress than the rotation plots, since it has been found that rotation systems could use soil water more efficiently [57].

\section{Conclusion}

Rainfall and soil moisture clearly had a large influence on the changes occurring in the soil microbial communities. 


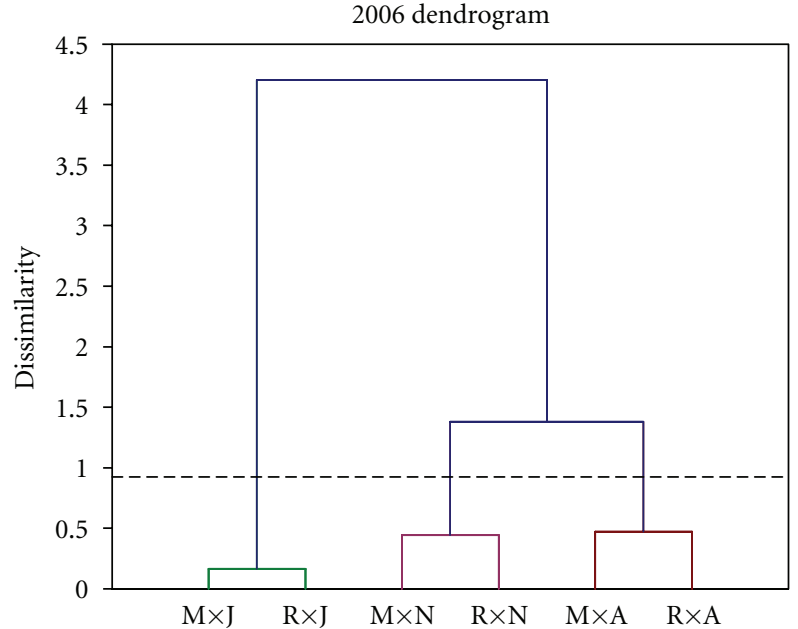

(a)

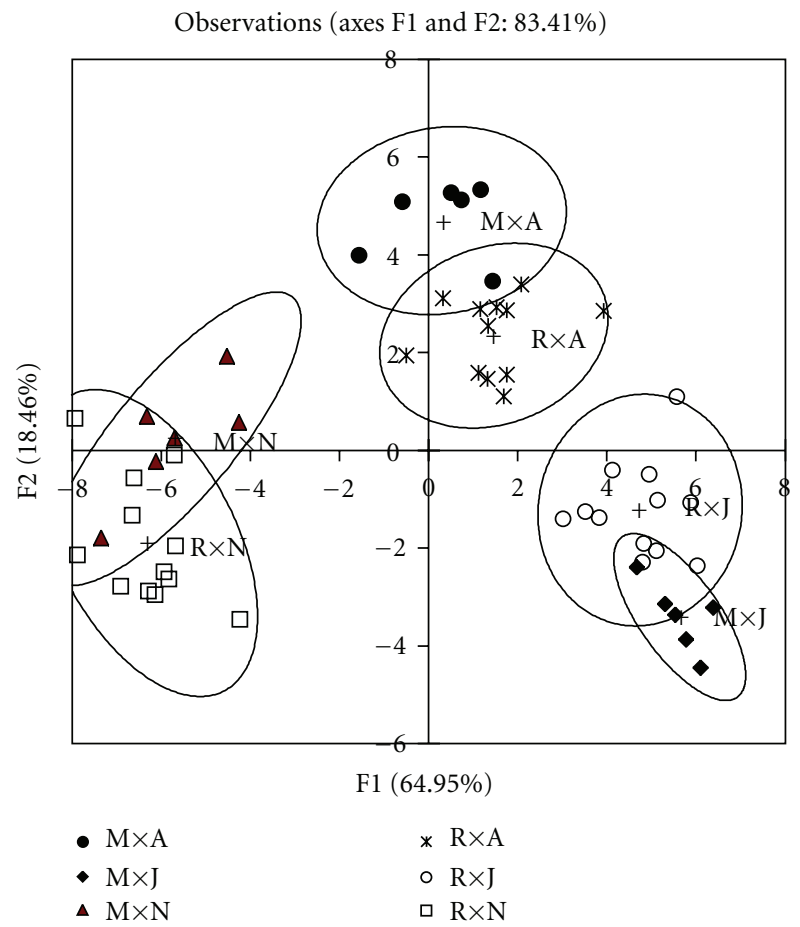

(b)

Figure 9: Results of cluster analyses conducted during 2006 on the community level physiological profiles of the soils, as measured using the Biolog EcoPlate method (a) dendrogram and (b) discriminant analysis (DA) $(\mathrm{M}=$ monoculture and $\mathrm{R}=$ rotation, $\mathrm{J}=$ June, $\mathrm{A}=$ August, and $\mathrm{N}=$ November $)$.

The seasonal fluctuation of wetting and drying in the Western Cape is probably the main driving force behind the changes in the soil microbial community, which can be seen throughout our results. It is, however, also clear that the agricultural management type had an effect on the culturable soil microbial community. It has to be kept in mind that the management practice at the test area had been in place for

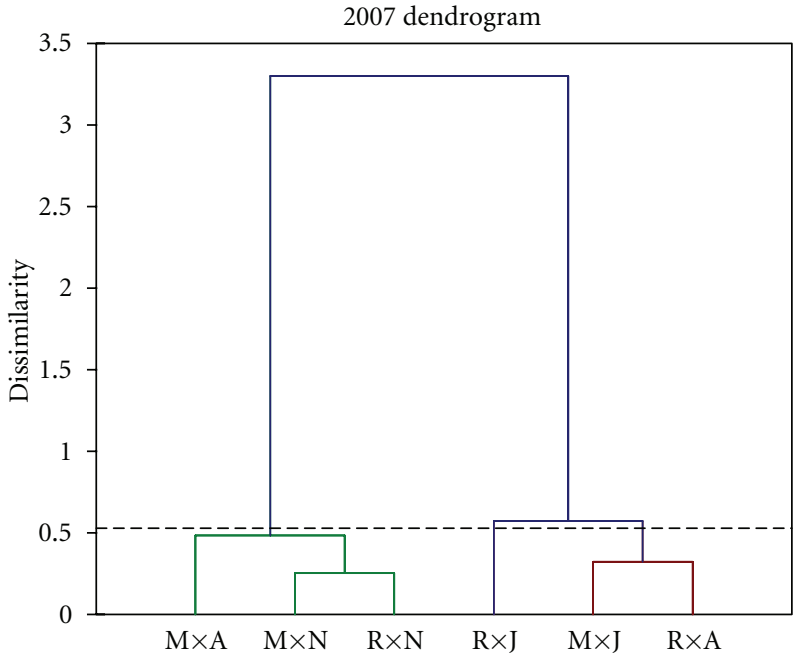

(a)

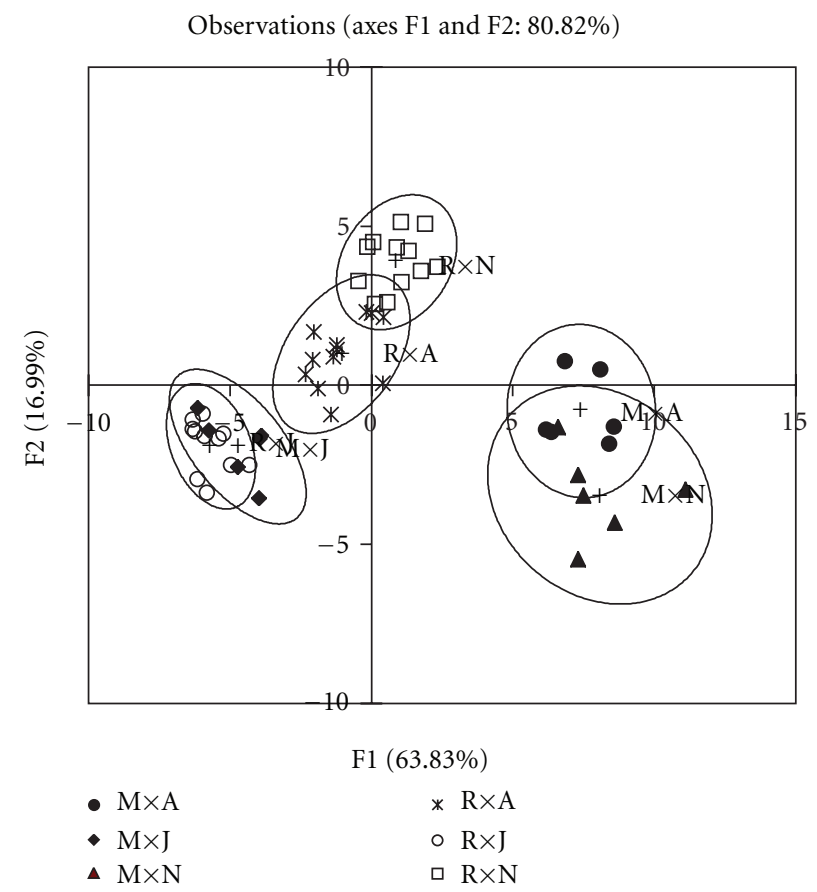

(b)

FIgURE 10: Results of cluster analyses conducted during 2007 on the community level physiological profiles of the soils, as measured using the Biolog EcoPlate method (a) dendrogram and (b) discriminant analysis (DA) $(\mathrm{M}=$ monoculture and $\mathrm{R}=$ rotation, $\mathrm{J}=$ June, $\mathrm{A}=$ August, and $\mathrm{N}=$ November $)$.

some years prior to this trial and that the wetting and drying cycles are part of the climate. It is thus possible that the soil microbial community had adapted to the specific practice as well as the dry-wet cycles, as reported by Fierer et al. [57] who concluded that dry-wet cycles can influence soil microbial communities, and that the communities evolve and adapt to the cycles over time. Since we did not identify any species but 


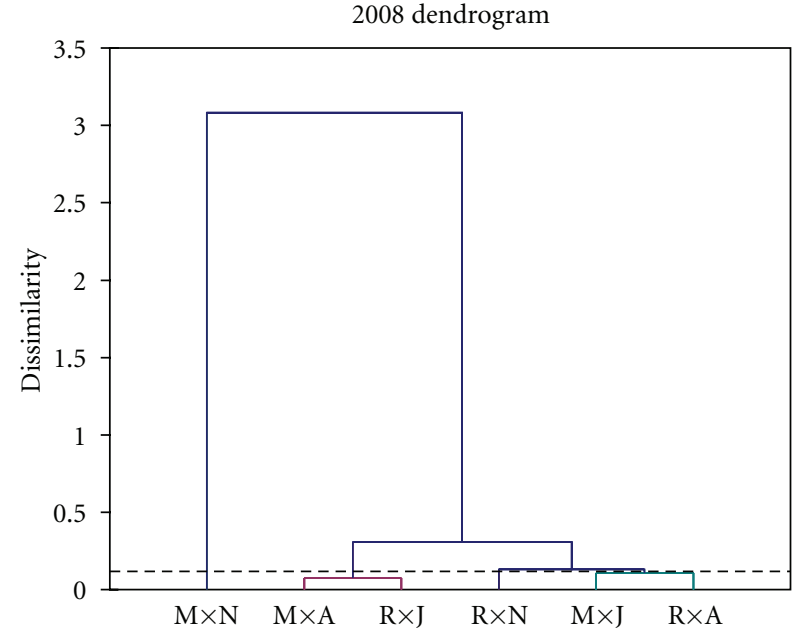

(a)

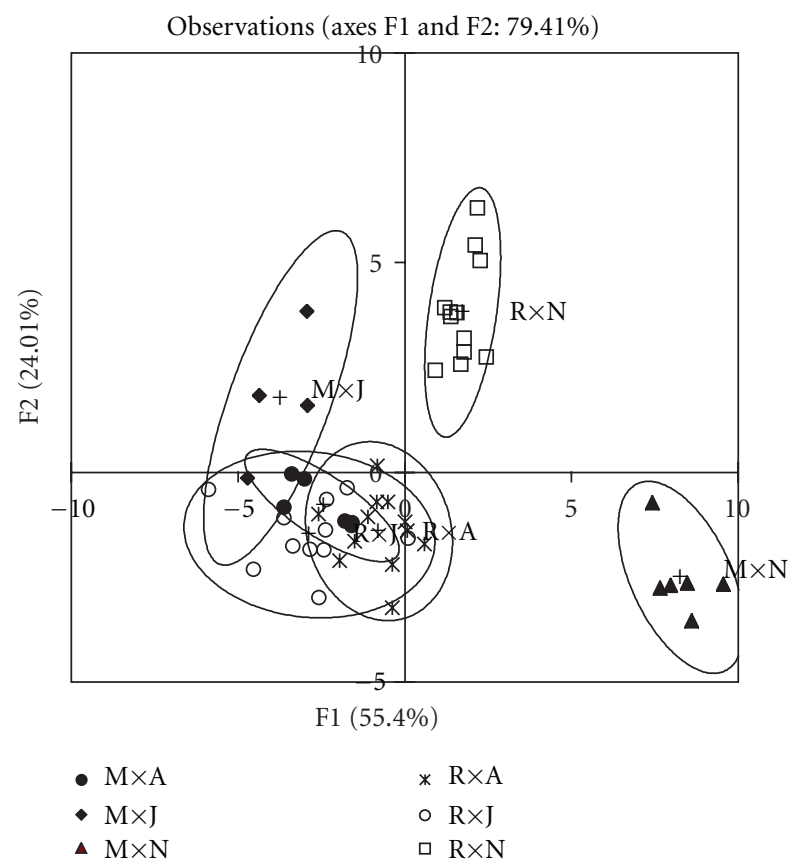

(b)

FIGURE 11: Results of cluster analyses conducted during 2008 on the community level physiological profiles of the soils, as measured using the Biolog EcoPlate method (a) dendrogram and (b) discriminant analysis (DA) $(\mathrm{M}=$ monoculture and $\mathrm{R}=$ rotation, $\mathrm{J}=$ June, $\mathrm{A}=$ August, and $\mathrm{N}=$ November).

observed the ecosystem profile of the soil community as a whole, it was not possible to deduct species-specific changes in these communities.

From our study it is clear that the use of culturable methods in soil microbiology is a tool that can be used to determine changes in ecosystem profiles of soil microbial communities.

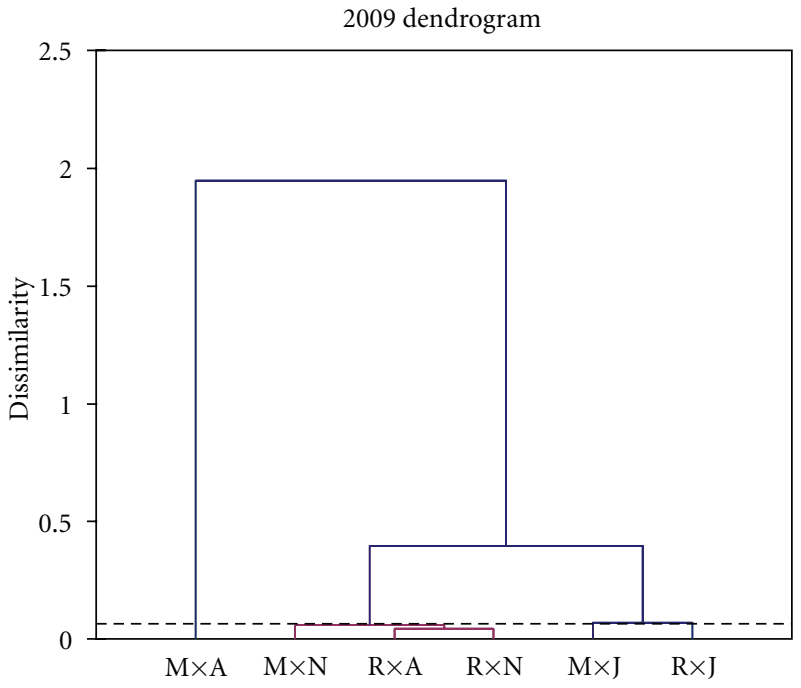

(a)

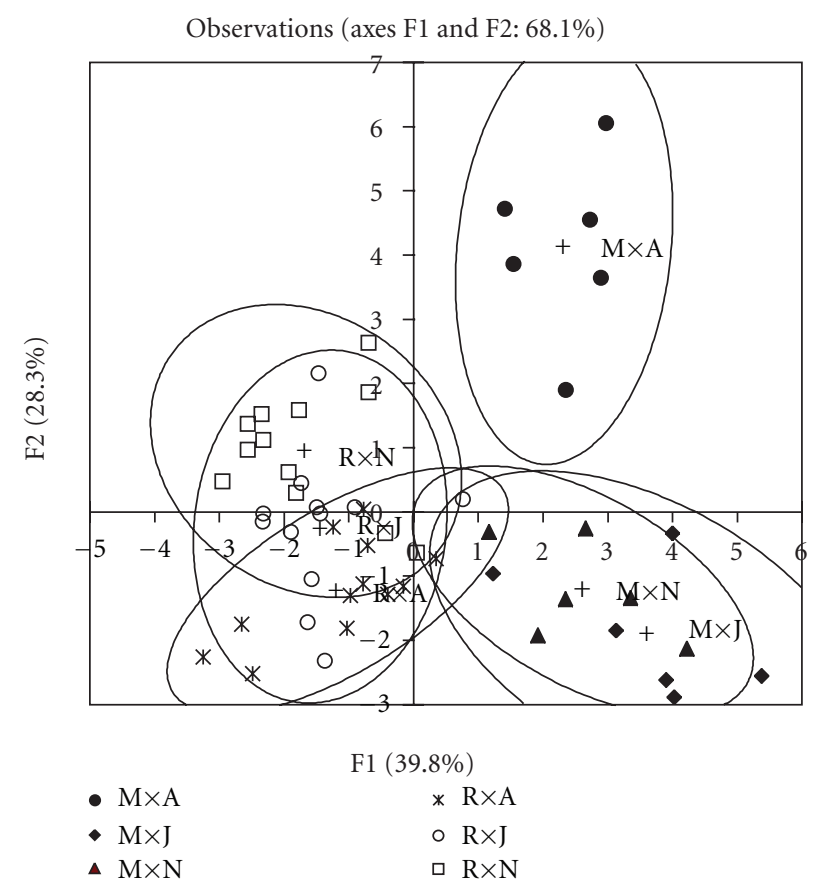

(b)

FIGURE 12: Results of cluster analyses conducted during 2009 on the community level physiological profiles of the soils, as measured using the Biolog EcoPlate method (a) dendrogram and (b) discriminant analysis $(\mathrm{M}=$ monoculture and $\mathrm{R}=$ rotation, $\mathrm{J}=$ June, $\mathrm{A}=$ August, and $\mathrm{N}=$ November).

\section{References}

[1] C. E. Pankhurst, "Evaluation of soil biological properties as potential bioindicators of soil health," Australian Journal of Experimental Agriculture, vol. 35, no. 7, pp. 1015-1028, 1995.

[2] P. J. Bottomley, "Microbial ecology," in Principles and Applications of Soil Microbiology, D. M. Sylvia, J. J. Fuhrmann, 
P. G. Hartel, and D. A. Zuberer, Eds., pp. 222-241, Pearson Prentice Hall, New Jersey, NJ, USA, 2nd edition, 2005.

[3] Anon, "NRCS: Soil Biology and Land Management Soil Quality," Soil Biology, Technical Note No. 4, 2004, http:// soils.usda.gov/sqi.

[4] J. A. W. Morgan, G. D. Bending, and P. J. White, "Biological costs and benefits to plant-microbe interactions in the rhizosphere," Journal of Experimental Botany, vol. 56, no. 417, pp. 1729-1739, 2005.

[5] J. C. Moore, K. McCann, and P. C. de Ruiter, "Soil rhizospere food webs, their stability, and implications for soil processes in ecosystems," in The Rhizospere-An Ecological Perspective, Z. G. Cardon and J. L. Whitbeck, Eds., pp. 101-125, Elsevier, Burlington, Mass, USA, 2007.

[6] A. D. Kent and E. W. Triplett, "Microbial communities and their interactions in soil and rhizosphere ecosystems," Annual Review of Microbiology, vol. 56, pp. 211-236, 2002.

[7] D. V. Murphy, E. A. Stockdale, P. C. Brookes, and K. W. T. Goulding, "Impact of microorganisms on chemical transformations in soil," in Soil Biological Fertility-A Key to Sustainable Land Use in Agriculture, L. K. Abbot and D. V. Murphy, Eds., pp. 37-59, Kluwer Academic, Dodrecht, The Netherlands, 2003.

[8] K. E. Dunfield and J. J. Germida, "Seasonal changes in the rhizosphere microbial communities associated with fieldgrown enetically modified canola (Brassica napus)," Applied and Environmental Microbiology, vol. 69, no. 12, pp. 7310 7318, 2003.

[9] P. Marschner, C. H. Yang, R. Lieberei, and D. E. Crowley, "Soil and plant specific effects on bacterial community composition in the rhizosphere," Soil Biology and Biochemistry, vol. 33, no. 11, pp. 1437-1445, 2001.

[10] M. D. C. A. González-Chávez, J. A. Aitkenhead-Peterson, T. J. Gentry, D. Zuberer, F. Hons, and R. Loeppert, "Soil microbial community, $\mathrm{C}, \mathrm{N}$, and $\mathrm{P}$ responses to long-term tillage and crop rotation," Soil and Tillage Research, vol. 106, no. 2, pp. 285-293, 2010.

[11] R. Doi and S. L. Ranamukhaarachchi, "Correlations between soil microbial and physicochemical variations in a rice paddy: implications for assessing soil health," Journal of Biosciences, vol. 34, no. 6, pp. 969-976, 2009.

[12] A. J. R. Reinecke and S. A. Reinecke, "Biodiversity in agricultural soils, sustainable plant production and control of plant pathogens," South African Journal of Science and Technology, vol. 29, no. 2, pp. 77-96, 2010.

[13] V. Torsvik, J. Goksoyr, and F. L. Daae, "High diversity in DNA of soil bacteria," Applied and Environmental Microbiology, vol. 56, no. 3, pp. 782-787, 1990.

[14] F. V. Wintzingerode, U. B. Göbel, and E. Stackebrandt, "Determination of microbial diversity in environmental samples: pitfalls of PCR-based rRNA analysis," FEMS Microbiology Reviews, vol. 21, no. 3, pp. 213-229, 1997.

[15] Ö. Ínceoğlu, E. F. Hoogwout, P. Hill, and J. D. van Elsas, “Effect of DNA extraction method on the apparent microbial diversity of soil," Applied and Environmental Microbiology, vol. 76, no. 10, pp. 3378-3382, 2010.

[16] R. I. Amann, W. Ludwig, and K. H. Schleifer, "Phylogenetic identification and in situ detection of individual microbial cells without cultivation," Microbiological Reviews, vol. 59, no. 1, pp. 143-169, 1995.

[17] N. Hall, "Advanced sequencing technologies and their wider impact in microbiology," Journal of Experimental Biology, vol. 210, no. 9, pp. 1518-1525, 2007.
[18] A. Ogram, H. Castro, A. Chauhan et al., "Methods of soil microbial community analysis," in Manual of Environmental Microbiology, J. C. Hurst, J. L. Garland, and A. L. Mills, Eds., pp. 652-662, ASM Press, Washington, DC, USA, 3rd edition, 2007.

[19] R. A. Olsen and L. R. Bakken, "Viability of soil bacteria: optimization of plate-counting technique and comparison between total counts and plate counts within different size groups," Microbial Ecology, vol. 13, no. 1, pp. 59-74, 1987.

[20] R. J. Ellis, P. Morgan, A. J. Weightman, and J. C. Fry, "Cultivation-dependent and -independent approaches for determining bacterial diversity in heavy-metal-contaminated soil," Applied and Environmental Microbiology, vol. 69, no. 6, pp. 3223-3230, 2003.

[21] S. L. Edenborn, A. J. Sextone, Y. Sutanto, and J. A. Chapman, "Relationships among contrasting measurements of microbial dynamics in pasture and organic farm soils," Applied and Environmental Soil Science, vol. 2011, Article ID 537459, 10 pages, 2011.

[22] A. C. Kennedy and K. L. Smith, "Soil microbial diversity and the sustainability of agricultural soils," Plant and Soil, vol. 170, no. 1, pp. 75-86, 1995.

[23] A. A. Yusuf, E. N. O. Iwuafor, R. C. Abaidoo, O. O. Olufajo, and N. Sanginga, "Effect of crop rotation and nitrogen fertilization on yield and nitrogen efficiency in maize in the northern Guinea savanna of Nigeria," African Journal of Agricultural Research, vol. 4, no. 10, pp. 913-921, 2009.

[24] P. M. Carr, G. B. Martin, and R. D. Horsley, "Impact of tillage and crop rotation on spring wheat yield: II. Rotation effect," Crop Management, 2006.

[25] C. N. Macvivar, R. F. Loxton, J. J. N. Lambrechts, J. le Roux, and J. M. de Villiers, Soil Classification: A Binomial System for South Africa, Department of Agricultural Technical Services, Pretoria, South Africa, 1977.

[26] Anon, Handbook of Standard Soil Testing Methods for Advisory Purposes, Complied by the Non-Affiliated Soil Analysis Work Committee, Soil, Science Society of South Africa, Pretoria, South Africa, 1990.

[27] K. R. du Plessis, A. Botha, L. Joubert, R. Bester, W. J. Conradie, and G. M. Wolfaardt, "Response of the microbial community to copper oxychloride in acidic sandy loam soil," Journal of Applied Microbiology, vol. 98, no. 4, pp. 901-909, 2005.

[28] R. M. Atlas, "Alphabetical listing of media," in Handbook of Microbiological Media, L. C. Parks, Ed., p. 666, CRC Press, London, UK, 1993.

[29] J. J. Worrall, "Media for selective isolation of hymenomycetes," Mycologia, vol. 83, no. 3, pp. 296-302, 1991.

[30] R. Rønn, F. Ekelund, and S. Christensen, "Optimizing soil extract and broth media for MPN-enumeration of naked amoebae and heterotrophic flagellates in soil," Pedobiologia, vol. 39, no. 1, pp. 10-19, 1995.

[31] A. M. Briones and W. Reichardt, "Estimating microbial population counts by "most probable number" using Microsoft Excel," Journal of Microbiological Methods, vol. 35, no. 2, pp. 157-161, 1999.

[32] J. L. Garland, "Potential and limitations of BIOLOG for microbialcommunity analysis," in Proceedings of the 8th International Symposium on Microbial Ecology Atlantic Canada Society for Microbial Ecology, C. R. Bell, M. Brylinsky, and P. Johnson-Green, Eds., pp. 1-7, Society for Microbial Ecology, 1999.

[33] D. Parkinson, T. R. G. Gray, and S. T. Williams, Eds., Methods for Studying the Ecology of Soil Micro-Organisms, Blackwell Scientific, Oxford, UK, 1971. 
[34] A. Marais, M. B. Hardy, C. D. Morris, and A. Botha, "Measuring culturable microbial populations and filamentous microbial growth in soil of wheat plots subjected to crop rotation and monoculture," South African Journal of Plant and Soil, vol. 27, no. 2, pp. 133-141, 2010.

[35] AOAC, Official Methods of Analysis, Association of Official Analytical Chemists, Arlington, Va, USA, 13th edition, 1985.

[36] L. Lisle, F. Lefroy, G. Anderson, and G. Blair, "Methods for the measurement of sulphur in plants and soils," Sulphur in Agriculture, vol. 18, no. 4, pp. 45-54, 1994.

[37] SAS Institute Inc, SAS Version 9.2, SAS Institute Inc, SAS Campus Drive, 6 Cary, North Carolina 27513, 2008.

[38] S. S. Shapiro and M. B. Wilk, "An analysis of variance test for normality 8 (complete samples)," Biometrika, vol. 52, pp. 591$561,1965$.

[39] R. L. Ott, An Introduction to Statistical Methods and Data Analysis, Duxbury Press, Belmont, Calif, USA, 1993.

[40] Anon, XLStat, Addinsoft, Paris, France, 2011.

[41] A. C. Rencher, Methods of Multivariate Analysis [Metodes vir Multiveranderlike Analise], John Wiley \& Sons, New York, NY, USA, 2nd edition, 2002, Simultaneously printed in Canada.

[42] V. J. Easton and J. H. McColl, Steps Statistic Glossary Version 1.1, 1997, http://www.stats.gla.ac.uk/steps/glossary/ anova.html\#intern.

[43] K. Mengel and E. A. Kirkby, Principles of Plant Nutrition, International Potash Institute, Berne, Switzerland, 2nd edition, 1979.

[44] T. M. Little and F. J. Hills, Statistical Methods in Agricultural Experiment, University of California, Davis, Calif, USA, 1972.

[45] H. O. Venterink, T. E. Davidsson, K. Kiehl, and L. Leonardson, "Impact of drying and re-wetting on N, P and K dynamics in a wetland soil," Plant and Soil, vol. 243, no. 1, pp. 119-130, 2002.

[46] P. H. Graham, "Biological dinitrogen fixation: symbiotic," in Principles and Applications of Soil Microbiology, D. M. Sylvia, J. J. Fuhrmann, P. G. Hartel, and D. A. Zuberer, Eds., pp. 222241, Pearson Prentice Hall, New Jersey, NJ, USA, 2nd edition, 2005.

[47] M. B. Hardy, "An investigation into the production of eight crop rotation systems, including wheat, canola, lupines and pasture species in the Swartland, Western Cape," Plant Production Yearly Report 2003/2004, Institute for Plant Production, Sub-Programme: Research, Agriculture Western Cape, Elsenburg, South Africa, 2004.

[48] M. B. Hardy, "An investigation into the production of eight crop rotationsystems, including wheat, canola, lupines and pasture species in the Swartland, Western Cape," Plant Production Yearly Report 2004/2005, Institute for Plant Production, Sub-Programme: Research, Agriculture Western Cape, Elsenburg, South Africa, 2005.

[49] V. Torsvik and L. Øvreås, "Microbial diversity and function in soil: from genes to ecosystems," Current Opinion in Microbiology, vol. 5, no. 3, pp. 240-245, 2002.

[50] A. Titus and G. N. Pereira, "The role of actinomycetes in coffee plantation ecology," 2005, http://www.ineedcoffee.com/ 05/actinomycetes/.

[51] M. Clarholm, "Protozoan grazing of bacteria in soil-impact and importance," Microbial Ecology, vol. 7, no. 4, pp. 343-350, 1981.

[52] R. Rønn, A. E. McCaig, B. S. Griffiths, and J. I. Prosser, "Impact of protozoan grazing on bacterial community structure in soil microcosms," Applied and Environmental Microbiology, vol. 68, no. 12, pp. 6094-6105, 2002.
[53] A. Bachar, A. Al-Ashhab, M. I. M. Soares et al., "Soil microbial abundance and diversity along a low precipitation gradient," Microbial Ecology, vol. 60, no. 2, pp. 453-461, 2010.

[54] B. O. Seabi, A. Botha, B. C. Viljoen, and C. Roux, "Nitrogen utilisation and growth at reduced water activity by mucoralean fungi present in soil," South African Journal of Botany, vol. 65, no. 5-6, pp. 407-413, 1999.

[55] N. Z. Lupwayi, W. A. Rice, and G. W. Clayton, "Soil microbial diversity and community structure under wheat as influenced by tillage and crop rotation," Soil Biology and Biochemistry, vol. 30, no. 13, pp. 1733-1741, 1998.

[56] A. Marais, M. I. Ferreira, M. Booyse, and A. Botha, "The effect of the herbicide Roundup, on some populations of soil microbes," South African Journal of Science and Technology, Artpages, 6 pages, 2011.

[57] N. Fierer, J. P. Schimel, and P. A. Holden, "Influence of dryingrewetting frequency on soil bacterial community structure," Microbial Ecology, vol. 45, no. 1, pp. 63-71, 2003. 

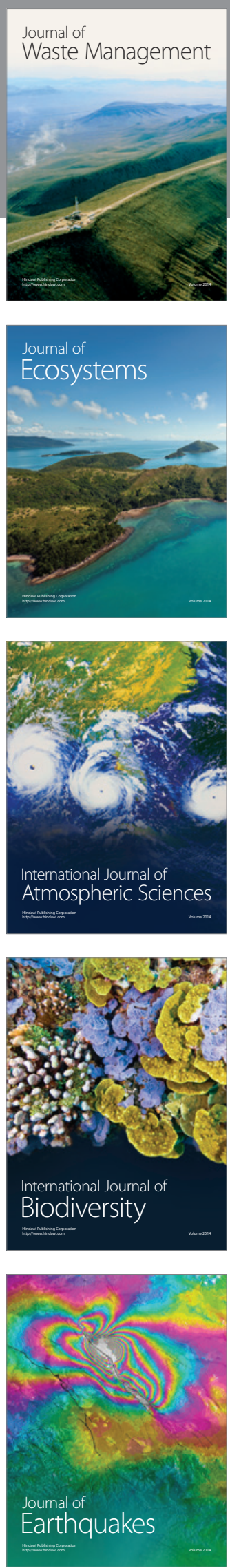
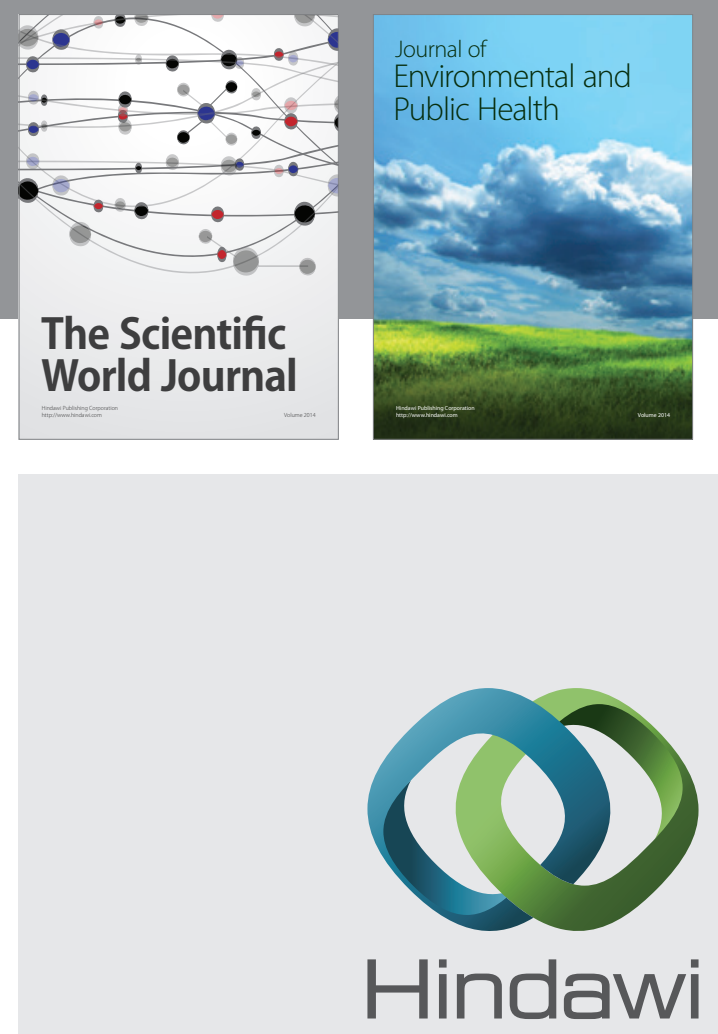

Submit your manuscripts at

http://www.hindawi.com
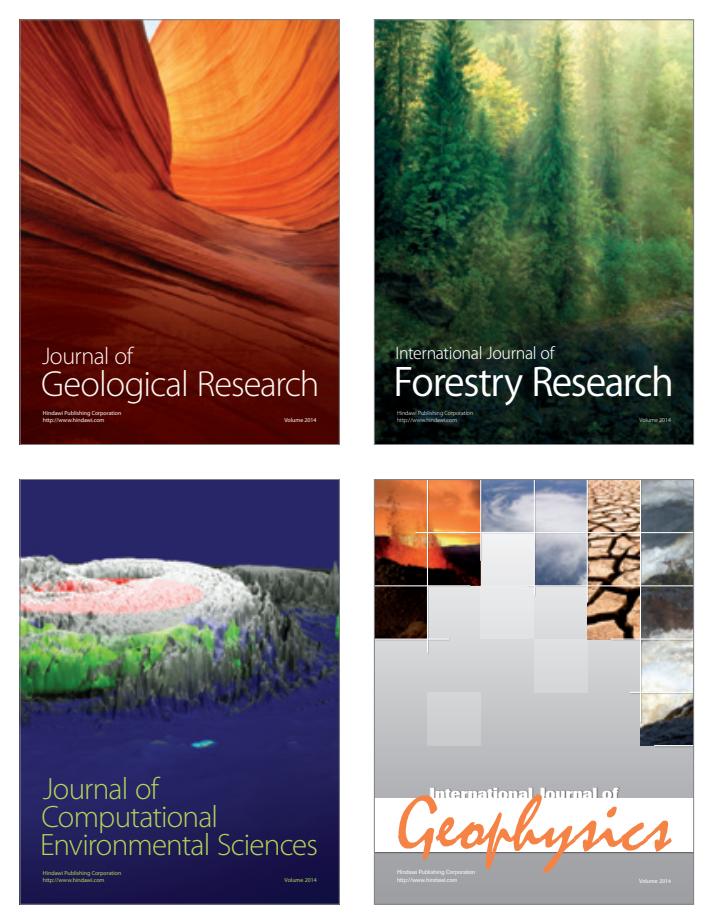
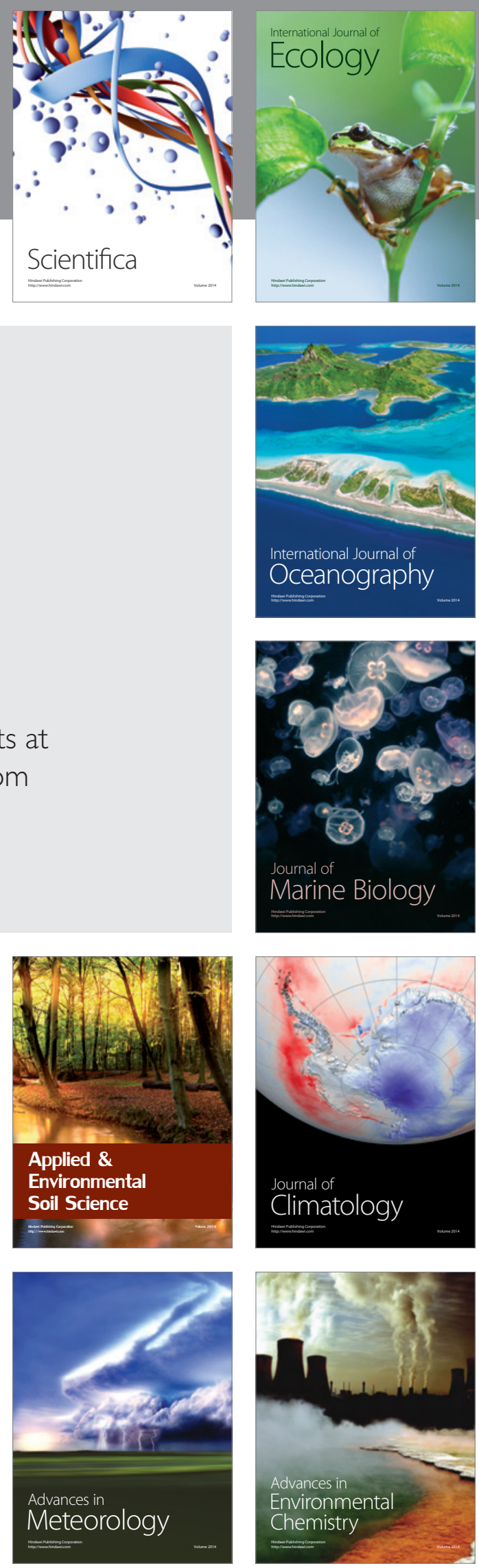